\title{
Comparation of Structure Between Malin Kundang and Si Tanggang Folktales
}

\author{
Tia Alfioda ${ }^{1, *}$ Yenni Hayati $^{1}$ \\ ${ }^{1}$ Universitas Negeri Padang, Padang, Sumatra Barat 25131, Indonesia \\ Corresponding author. Email : hantiaalfioda@ gmail.com
}

\begin{abstract}
Folklore is one of the oral literary traditions in the world of Indonesian literature. The birth of a literary work cannot be separated from the existence of literary works that preceded it, which have been absorbed by writers. Each region has folklore. Folklore has its own place in an area. One of them is the Padang area and Malaysia, namely Malin Kundang and Si Tatang. In this study, the researcher used a qualitative research method of comparative analysis description with a structural objective approach to the literary work itself. By using this approach, we get a description of the similarities and differences from the two data sources.
\end{abstract}

Keywords: comparative literature, structural studies, folklore

\section{INTRODUCTION}

Folklore can not be separated from the community considering folklore can be a symbol of an region. According to Dananjaja [1], folklore is a culture that is passed down from generation to generation in different versions, both orally and accompanied by reminders. Wherever the area is, there must be folklore that is told from generation to generation, usually containing moral teachings and very valuable for the community [2]. In folklore, usually the main character teaches moral values that we encounter everyday [3]. Folklore is told from generation to generation because of that folklore is called anonymous. Folklore is very different from historical stories. Historical stories must be based on facts while folklore is oral literature that is told from generation to generation according to the memory of the listener. This is why folklore has many different versions.

One that has almost the same folklore is Malin Kundang from the Padang area and $\mathrm{Si}$ Tatang from Malaysia. Malin Kundang is a folktale that is told from generation to generation in the Padang community. Malin Kundang told a story of a child who was disobedient to his mother. This child is said to have no father and has a hard life, then he wanders off to change his fate. This is in line with the habits of the Padang people who like to wander. In the story, the ladder also tells the story of a child who is disobedient to his mother. There are similarities and differences between the two folktales.

The relationship between the folklore of Malin Kundang and Si Tangang is the basis for the author to conduct research and prove that these literary works are related. The author examines from a structural point of view in order to be able to compare the two stories. This structural study aims to describe the relationship and produce an overall picture of the two folklores.

In addition to seeing the relationship, literature can also be used as a tool to educate. In its structure, it is contained in the message of the story or also known as the mandate. Usually in folklore there are customary laws, local people's habits and religious elements.

\section{METHOD}

This research applied a descriptive qualitative method. Moleong [4] explains that qualitative researc is a systematic statement related to a set of prepositions, and derived from that basis. Data collection in this study is by tracing the sources of story information, as well as literature review.

The source of data in this study is the folklore of Malin Kundang and si Tanggang. These folk tales were chosen because they are related and almost similar to one another.

\section{RESULTS AND DISCUSSION}

Damono conceptualizes structural analysis based on the following: 1) The facts of the story which include plot, characters, and setting. 2) Themes. 3) Literary tools which include title, point of view, style and tone. The following section is a comparison of the stories of Malin Kundang and Si Tanggang. 


\subsection{Malin Kundang}

The story of Malin Kundang is one of the folk tales originating from Sumatra. This story tells about Malin Kundang who comes from a poor family. He lived with his mother, while his father had been away for a long time but did not return. Malin Kundang grew into an adult because of economic limitations. Until one day he met a ship's captain. He wanted to migrate to change his fate. He also asked permission from his mother. Although with a heavy heart, the mother let go of Malin Kundang's departure. Years passed Malin Kundang worked in overseas land. In the overseas lands, Malin Kundang worked very hard, immediately he became a rich merchant. He later married a rich merchant's daughter. The merchant had many large ships for his trade affairs. Malin Kundang with his beautiful wife then often traveled in business matters. In his hometown, news of Malin Kundang's success has often been heard by his mother, who is now old and frail. The old woman missed her son very much. He was sure that one day his son who was dashing and rich would pick him up. Every afternoon he waited for Malin Kundang at the pier. He hoped that Malin Kundang would pick him up.

On a quiet afternoon, a large ship docked at the pier where Malin Kundang's mother sat faithfully waiting. When the rich merchant who owned the ship and his wife came out standing at the bow of the ship, Malin Kundang's mother was sure that the rich merchant was her son. The beautiful clothes and all the jewelry attached to her child's body did not blind her eyes. He can still recognize Malin Kundang. The old woman was even more convinced when she saw the scar on her son's hand. The wound fell when Malin Kundang chased the chicks. Malin Kundang's mother immediately hugged her son when the merchant got off the ship with his wife. He expressed his joy that his son Malin Kundang had become a successful person overseas. However, it was beyond his mother's expectations. Malin Kundang felt ashamed to have an old mother with tattered bad clothes.

In front of his wife, he said that he was not the daughter of the old woman. Malin Kundang's mother was really hurt. The only child he loved so much had hurt him. He tried to convince Malin Kundang that he was indeed his mother. But Malin Kundang, who just because he was ashamed of having an ugly mother, kept trying to refute. He even got angry. Malin Kundang shouted and pushed his mother to the ground. Malin Kundang also left his mother who was still lying on the ground. Finally, the old woman gave up and prayed to God. Instantly Malin Kundang turned to stone.

\subsubsection{The structural analysis of Malin Kundang}

In analysis with a structural approach, the structure of folklore includes the factual structure or story facts (plot, characters, background), themes, and literary means (title, point of view, style and tone). Orally, the folklore of Malin Kundang uses a forward plot.

Character analysis in Malin Kundang folklore refers to the analysis of the main character and subordinate characters. The main character in the folklore of Malin Kundang is Malin. In the folklore, Malin Kundang is the story of what happened in his life. The character of the malin character was initially described as a polite, polite, kind, obedient child to his parents and diligent in working. Malin's character is present from the beginning of the story, while other characters refer to the process of Malin's life until the end of the story. There are 4 subordinate characters in the Malin Kundang folklore. Among them are Malin Kundang's mother, a rich merchant, Malin Kundang's wife and bodyguards.

The background analysis in the Malin Kundang folklore includes place, time and social settings. The setting of the place contained in the folklore of Malin Kundang include: huts, the sea, ships and the beach. The time setting is described by the author in ancient times. However, the time or year is not explained. The social setting in the Malin Kundang folklore describes the social life of the Padang people who like to migrate to change their fate.

Based on the researcher's observations, the content of the story and the conflicts contained in the Malin Kundang story are the struggle, the love of a mother and karma for those who are disobedient to the mother. The conflict began when Malin asked his mother for permission to migrate. When Malin migrated he was active and a rich merchant was interested in making him his son-in-law. Then he married the merchant's son. When Malin achieved success he returned to his hometown and he did not recognize his mother.

The point of view of the folklore is third person omniscient. With a third point of view refers to each character and positions them in the third person. The third person point of view allows the reader to know everything.

\subsection{Si Tanggang}

This folk tale tells about Si Tanggang in Malaysia. Si Tanggang is the son of Si Talang and Si Deruma. Their family life is very poor. Si Tanggang always dreamed of becoming rich and famous. One day, Si Tanggang saw a large ship anchored at the mouth of a river close to his house. Si Tanggang went to meet the captain of the ship and asked to be made his crew. The captain of the ship immediately agreed because he had seen the efficiency of Si Tanggang's boat and work. Although Si Talang and Si Deruma strongly objected to letting Si Tanggang sail according to the captain's ship, they were forced to give 
in. Si Tanggang promised to return to the village after becoming rich. The Tanggang did whatever the master ordered. The skipper really likes him because he works hard. Then, Si Tanggang was taken as an adopted son. If the captain becomes old, then Si Tanggang is appointed as the new captain. He is called Tanggang skipper.

Si Tanggang is efficient and good at business. His name became famous. So he was invited by the Sultan to the palace. Not long after, Si Tanggang married the Sultan's daughter. The Tanggang took his wife sailing to many places throughout the country. One day Si Tanggang's ship docked at the mouth of the river of his home village. The villagers know that the captain of the ship is $\mathrm{Si}$ Tanggang. They also told their parents. Tanggang's parents were very happy.

Si Talang and Si Deruma Tanggang's father and mother went to pedal the canoe to the captain of Tanggang's ship. Si Deruma brought Si Tanggang's favorite food, namely salai bananas. When they arrived on the ship, a crew member forbade them to board. A moment later, The Tanggang appeared with his wife. The ladder asked his men about the identities of the two parents. The subordinate said that the two parents were the parents of the Tanggang himself. Hearing this statement, $\mathrm{Si}$ Tanggang was very embarrassed. He chased the parents away and off they went. Arriving in the middle of the sea came a big wave that made Si Tanggang's ship and all its contents turned to stone.

\subsubsection{Structural Analysis of Si Tanggang}

Folklore Si Tanggang folklore is analyzed through a structural approach covering story facts (plot, characters, setting), themes and literary means (title, point of view, style and tone). The flow shown is the forward flow. Analysis of the characters in the folklore of the ladder refers to the main and subordinate characters. Based on the story, there are 6 subordinate characters. Among them are the Talang's father, the Deulima, the Talang's mother, the captain, the sultan, the Talang's wife and bodyguards.

Analysis of the background in the folklore of the ladder includes the setting of place, time and social background. The setting in the following story is a house, a ship and a palace. The time setting that is displayed uses only ancient words. The social setting of the story of the ladder is about the life of a man who is tenacious in trying his luck. The conflict is not much different from the folklore of Malin Kundang. The story of Si Tanggang also uses a third person point of view.

In the character there is a slight difference between the ladder and malin kundang. In the folklore of Malin Kundang, the only parent he has is a mother, this indicates the identity of the area, namely the Padang. Padang, where the Minang people follow the matrinileal mother line. While in the Tanggang folklore he has a mother and father. But when cursing, the one who curses the child is still the mother. The curse given to the folklore of Malin Kundang and Si Tanggang is the same, namely being cursed to be stone. The following table is a comparison of the structure between Malin Kundang and Si Tanggang.

Table 1. Similarities and Differences between Malin Kundang and Si Tanggang

\begin{tabular}{|c|c|}
\hline Structure of & Synopsis \\
\hline Similarities in & $\begin{array}{l}\text { Malin Kundang } \\
\text { Theme The theme is divided into two major themes and minor themes. (a) the theme of the story } \\
\text { of malin kundang is a child who initially went abroad and returned to his village. The boy } \\
\text { disowned his mother and was cursed. } \\
\text { Si Tanggang } \\
\text { Not much different from the story of Malin Kundang, the story of Si Tanggang is also about a } \\
\text { child who wanders and returns to his village after success. The child disowned his parents and } \\
\text { was cursed. }\end{array}$ \\
\hline Theme & There is no difference in the theme \\
\hline $\begin{array}{l}\text { Similarities of } \\
\text { Characters and the } \\
\text { characterizations of }\end{array}$ & $\begin{array}{l}\text { Malin Kundang } \\
\text { The character in this story is a man who is tenacious. His intention to change fate is very big. } \\
\text { Malin's character can be trusted so that the rich merchants believe in him. The character of } \\
\text { malin is also ungodly. }\end{array}$ \\
\hline
\end{tabular}




\begin{tabular}{|c|c|}
\hline & $\begin{array}{l}\text { Si Tanggang } \\
\text { character in this story is no different from malin kundang, the ladder, a tenacious man who } \\
\text { changes fate and is also disobedient. }\end{array}$ \\
\hline Characters & There is no difference in the characters \\
\hline Plot & $\begin{array}{l}\text { Malin Kundang } \\
\text { Flow at Malin Kundang story is developed, according by the order in which occur in sequence. } \\
\text { Si Tanggang } \\
\text { The plot in Si Tanggang's story is a forward plot, based on the time sequence that occurs } \\
\text { sequentially and chronologically. }\end{array}$ \\
\hline Differences in Plot & There is no difference in Plot Structure \\
\hline Setting & $\begin{array}{l}\text { Malin Kundang } \\
\text { Similarities The setting of this story is the house, the sea, the beach and the ship. } \\
\text { Si Tanggang } \\
\text { Equation The setting of this story is the house, the sea, the beach and the ship. }\end{array}$ \\
\hline $\begin{array}{l}\text { Differences in } \\
\text { Background }\end{array}$ & There is no difference in the Motif of the story \\
\hline Motif & $\begin{array}{l}\text { Malin Kundang } \\
\text { We should not fight against our parents because the pleasure of Allah is the pleasure of our } \\
\text { parents. } \\
\text { Si Tanggang } \\
\text { We should not fight against our parents because the pleasure of Allah is the pleasure of our } \\
\text { parents. }\end{array}$ \\
\hline
\end{tabular}

\section{CONCLUSION}

The folklore of Malin Kundang and Si Tanggang comes from two different regions, one from Padang and the other from Malaysia. However, these two stories have elements of similarities and differences. The elements explored in this research are theme, plot, characters and characterizations, background and mandate. The male character in the story has a tenacious but disobedient nature. The theme in this story is a child who is disobedient to his parents. The plot used in the story is a forward plot. The setting in the story of Malin Kundang and Si Tanggang are houses, beaches, shores and ships. The message conveyed from the two stories is never to fight against your parents since the blessing of Allah is in the blessing of parents.

\section{REFERENCES}

[1] J. Danadjaja, Folklor Indonesia: ilmu gosip, dongeng dan lain-lain. Jakarta: Grafiti Press, 1988.

[2] Asmawati, Y. Hayati, I. G. D. Pertiwi, and M. Adek, "'Birds of a Feather Flock Together': The Comparison Between Two Folklores Bawang Merah Bawang Putih and Putri Arabella," in Proceedings of the 3rd International Conference on Language, Literature, Culture, and Education (ICOLLITE 2019), 2020.

[3] R. Revika and Y. Hayati, "Categories, structure, and function of folklore in Lima puluh district communities," RETORIKA J. Bhs. Sastra dan Pengajarannya, vol. 13, no. 1, p. 137, 2020.

[4] L. J. Moleong, Metodologi Penelitian Kualitatif. Bandung: Remaja Rosda Karya, 2007. 